\title{
ON SELECTED MORPHOMECHANICAL CHARACTERISTICS OF SIGNAL CRAYFISH (PACIFASTACUS LENIUSCULUS DANA) EGGS DURING INCUBATION
}

\author{
A. WINNICKI (1), D. PAWLOS (1), K. FORMICKI (1), P. SMIETANA (2)
}

(1) Department of Fish Anatomy and Embryology, Agricultural University of Szczecin, Poland,

E-Mail: embryo@fish.ar.szczecin.pl

(2) Department of Ecology, University of Szczecin, Poland

Reçu le 6 janvier 2004

Received January 06, 2004

Accepté le 11 octobre 2004

Accepted October 11, 2004

\section{ABSTRACT}

Changes in resistance to mechanical pressure during embryogenesis were studied in the signal crayfish (Pacifastacus leniusculus Dana). A constant increase in egg size (volume and surface area) was observed to take place throughout the embryonic development, the increase occurring as most probably result of water absorption. The increase in the egg volume was found to be accompanied by a constant reduction in the egg membrane resistance.

Morphomechanical aspects of crayfish hatching as well as a possibility of taking advantage of them to enhance astacid reproduction are discussed.

Key-words: signal crayfish, embryogenesis, egg membrane resistance.

\section{SÉLECTION DES CARACTÉRISTIQUES MORPHOMÉCANIQUES DES OEUFS DE L'ÉCREVISSE SIGNAL (PACIFASTACUS LENIUSCULUS DANA) PENDANT L'INCUBATION.}

\section{RÉSUMÉ}

Les changements de résistances sous l'effet d'une pression externe pendant l'embryogenèse chez l'écrevisse signal (Pacifastacus leniusculus Dana) ont été étudiés. Une augmentation constante de la taille de l'œuf (volume et surface), due à l'absorption d'eau, a été observée pendant tout le développement embryonnaire. II a été montré que l'accroissement du volume de l'œuf était accompagné d'une réduction constante de la résistance de la membrane de cet œuf.

Les aspects morphomécaniques du système d'éclosion des écrevisses ainsi que la possibilité d'en tirer profit pour améliorer la reproduction des astacidés sont discutés.

Mots-clés : écrevisse signal, embryogenèse, résistance des œufs. 


\section{INTRODUCTION}

For time immemorial, crayfish have been an important component of European freshwater fisheries. As indicated by annual consumption data, the crayfish species such as the noble crayfish (Astacus astacus L.) and even the narrow-clawed crayfish (Astacus leptodactylus Esch.) have long been sought after by consumers, up to several thousand tonnes being sold each year. Unfortunately, due to constantly deteriorating environmental conditions and epidemics of crayfish plague, the crayfish populations, and hence their consumption in Europe, have been for some time reduced.

Owing to its innate immunity to the crayfish plague (caused by the pathogen Aphanomyces astaci Schikora), the signal crayfish has no difficulty in breeding in Europe. In the 1970s, the crayfish was introduced in Poland where it found favourable conditions for life and reproduction (KOSSAKOWSKI et al., 1978; KRZYWOSZ, 1994; ŚMIETANA and STRUŻYŃSKI, 1996).

Artificial incubation of astacids is one of the measures undertaken to prevent extinction of species and to culture them. Losses incurred during artificial incubation are very poorly known. Differences in mortality between natural and artificial incubation may occur because the first proceeds in an ideal natural incubator formed by the specific brood chamber a female constructs by curling her abdomen. In addition, throughout the incubation period, the eggs are permanently attached to the internal structures of that quasi-brood chamber. Removal of the eggs during early embryogenesis can mechanically damage the structure of the external egg membrane, formed - when the eggs are laid - from a secretion of special glands located near the outlets of the ovaries. On contact with water, the secretion becomes dense and forms a strong and elastic membrane as well as filamentous connectors (stalks) with which the eggs are attached to the pleopods. Should that entire structure be damaged, the egg's water exchange would be impaired and the egg could be easily penetrated by microorganisms (e.g., bacteria).

It was for those reasons that the authors were prompted to take a closer look at mechanical properties of the egg membrane in conjunction with changes in the egg water budget. As opposed to incubatable (also in vitro) eggs of aquatic vertebrates, eggs of other decapods are already known (WINNICKI and SŁOMIANKO, 1970) to increase in volume as the embryonic development progresses, the egg volume reaching its maximum at hatching.

Should that be the case in the crayfish as well, and should the increase in egg volume be associated with egg membrane resistance, it could be perhaps possible to develop a technique for artificial incubation and, most importantly, cast new light on crayfish reproduction. Although the crayfish life cycles, biology, and morphogenesis have already been studied and described in detail (LEREBOULLET, 1862; HUXLEY, 1877; SUKO, 1956; CELADA et al., 1987), embryophysiological processes, hatching mechanisms in particular, remain - to a large extent - rather obscure.

\section{MATERIALS AND METHODS}

The study was carried out from November 2001 until March 2002 at the Department of Fish Anatomy and Embryology, Agricultural University of Szczecin, North-western Poland.

The study involved eggs obtained from 4-year-old females of the signal crayfish (P. leniusculus Dana). The crayfish total body length measured $9.5-13.1 \mathrm{~cm}$. Throughout the period of study, individual females were kept in separate 60-I tanks equipped with hide-outs and wrapped in black plastic sheets to eliminate all external stressful factors (movements of laboratory personnel, changes in light regime, etc.). Water in the tanks was 
constantly aerated. To keep the tank water clean, a half of its volume was exchanged every 3 days. The females were fed ad libitum with fresh fish, boiled potatoes, and carrots. The photoperiod regime was maintained by appropriately changing external artificial lighting. The temperature was dependent on the external temperature and ranged from $4^{\circ} \mathrm{C}$ at the onset of the experiment to $18^{\circ} \mathrm{C}$ at the end.

Throughout the experiment, the eggs were incubated under natural conditions provided by the female brood chambers, i.e., the eggs were suspended on the females' abdominal appendages.

Prior to each test, a batch of 12 eggs was collected from each female by carefully separating the eggs from the female's appendages with a pair of silicone-coated forceps. To further reduce the probability of damaging the egg membranes, the eggs were handled by picking them by their stalks. The eggs were transported, in water-filled vessels, to the laboratory where they were examined under the stereomicroscope. Subsequently, each egg's volume was calculated following measurement (to $0.01 \mathrm{~mm}$ ) of two diameters with the MultiScan v. 13.01 software. The eggs were then tested for their resistance to crushing in a special device that recorded (to $0.1 \mathrm{~g}$ ) the pressure, exerted on an egg, at which the egg membrane was breaking down (Fig. 1).

The measurements were taken and the tests were performed 4 times during embryogenesis, i.e., after $300,500,700$, and $900 \mathrm{D}^{\circ}$. The intention was to collect data, amenable to statistical treatment, which would provide a basis from which to draw conclusions on egg water absorption dynamics and the associated changes in egg membrane resistance. Although care was taken to test a possibly representative sample of

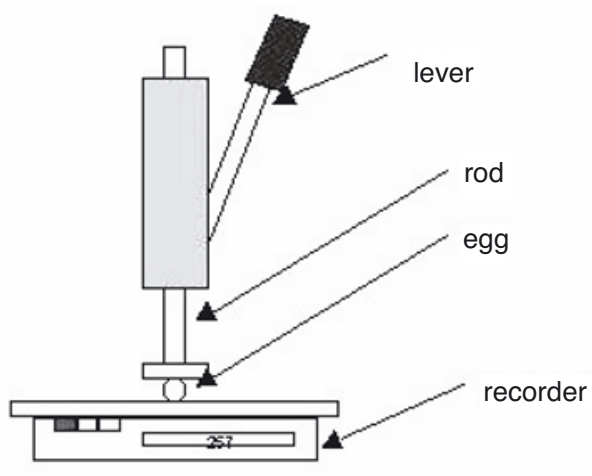

\section{Figure 1}

A device for testing the signal crayfish (Pacifastacus leniusculus Dana) egg membrane resistance. The rod with which the pressure is exerted upon an egg was placed in a guide that ensured uninterrupted rod movement and pressure. The downward rod movement at a constant speed was triggered by a lever. The recorder registered the maximum pressure force causing the egg membrane to break down.

\section{Figure 1}

Un dispositif pour tester la résistance membranaire de l'écrevisse signal (Pacifastacus leniusculus Dana). La tige avec laquelle la pression est exercée sur l'œuf est placée dans un guide qui assure un mouvement et une pression continue. Le mouvement de haut en bas de la tige à vitesse constante est déclenché par un levier. La pression maximale rompant la membrane est enregistrée par l'appareil. 
eggs, a low individual fecundity of the crayfish females (from a few tens to several hundred eggs) as well as the need to reduce potential losses generated by frequent handling resulted in limiting the number of measurement series to 4 .

The data obtained were analysed by non-parametric Kruskal-Wallis test, applied with the aid of Statistica v. 6.05 software.

\section{RESULTS}

On close inspection, the egg size data collected revealed certain regularities. When examined even with a naked eye, the eggs were seen to comply with the general decapod egg shape pattern, whereby the eggs, instead of being regularly spherical, were clearly oval, a shape maintained throughout the period of incubation. At its terminal stage, the oval shape was even more pronounced than early on during embryogenesis (HAMR, 1992) (Fig. 2).

Interestingly increase in the egg diameter during embryogenesis was fairly uniform and was directly reflected in the volume increase (by 52\%) that defined the amount of water absorbed at that time (Fig. 3). Differences in egg volume between individual measurement series were statistically significant (Kruskal-Wallis Test; $H(d f=3, N=264)=163.862$ : $p<0.001)$ as well as between all groups $(p<0.0001)$, except difference observed between $700 D^{\circ}$ and $900 D^{\circ}(p=0.07)$. The egg surface increased as well, thus increasing the total respiratory surface, and hence the respiration efficiency of an embryo. As shown by the calculations, the respiratory surface of an egg increased from $18.6 \mathrm{~mm}^{2}$ at $300 \mathrm{D}^{\circ}$ to $24.8 \mathrm{~mm}^{2}$ at $900 \mathrm{D}^{\circ}$, that is by $25 \%$.

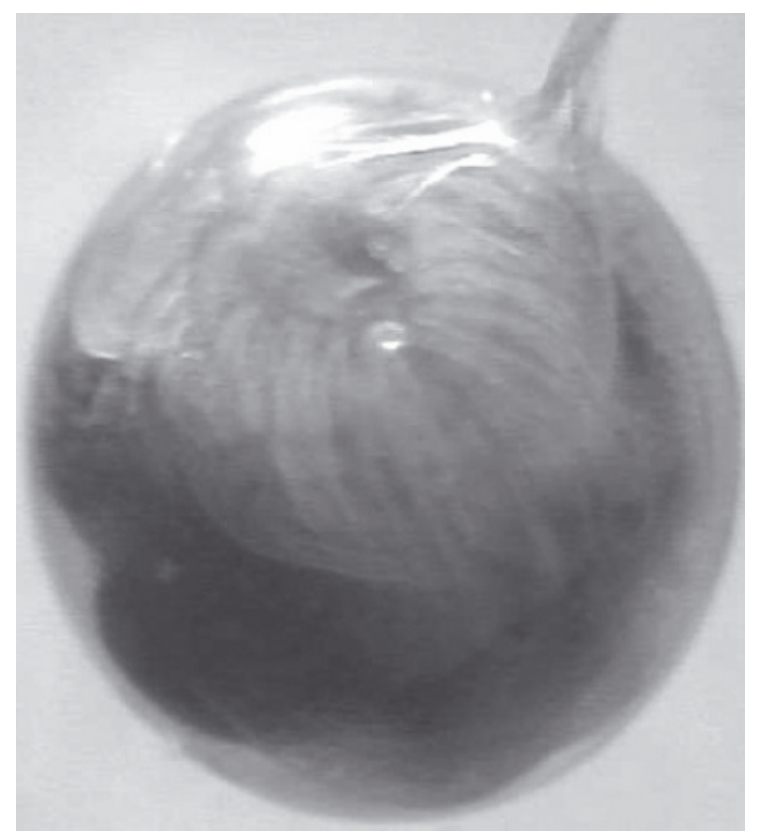

Figure 2

Signal crayfish ( $P$. leniusculus Dana) egg.

\section{Figure 2}

Oeufs d'écrevisses signal ( $P$. leniusculus Dana). 


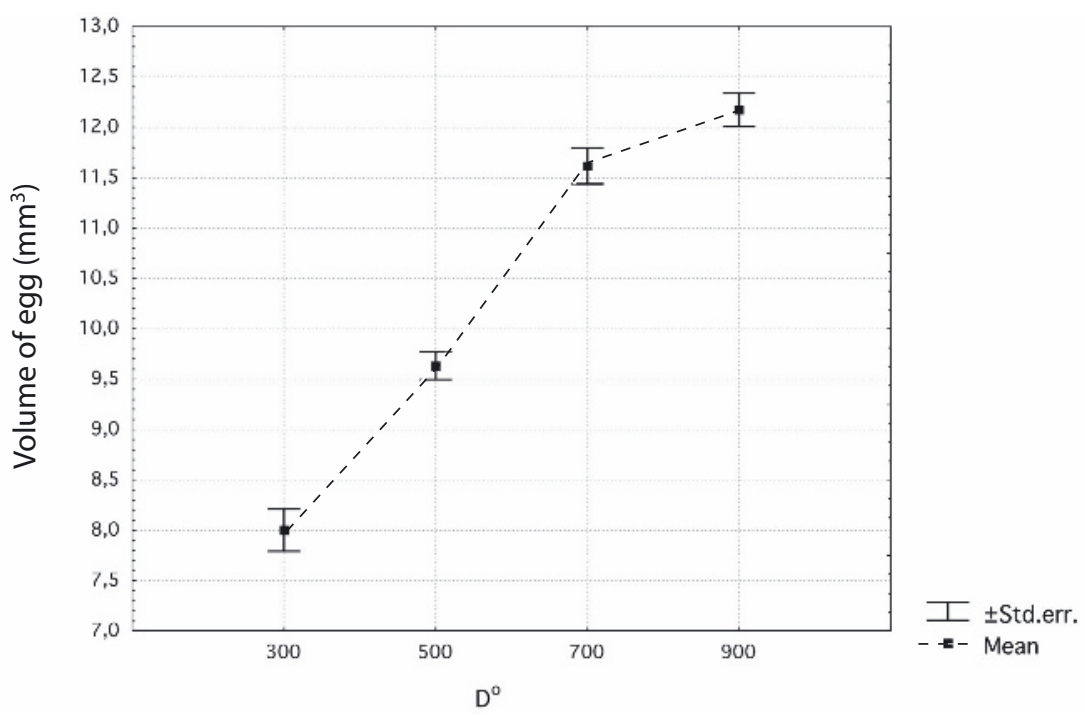

\section{Figure 3}

Changes in the signal crayfish ( $P$. leniusculus Dana) egg volume during embryogenesis. Kruskal-Wallis Test; $H(d f=3, N=264)=163.862 ; p<0.001$.

\section{Figure 3}

Variations du volume des œufs de l'écrevisse signal ( $P$. leniusculus Dana) durant l'embryogenèse. Kruskal-Wallis Test; $H(d f=3, N=264)=163.862 ; p<0.001$.

Tests for egg resistance to crushing (a measure of mechanical resistance of egg membranes) demonstrated firstly, a substantial mechanical resistance of the signal crayfish egg membrane: the resistance exceeded $100 \mathrm{~g}$, i.e., 0.5 atmosphere; secondly, a steady reduction in egg resistance to crushing (membrane resistance to break-down) during embryonic development (Fig. 4). Differences during the egg development in egg membrane resistance were statistically significant in total (Kruskal-Wallis Test; $\mathrm{H}(\mathrm{df}=3$, $\mathrm{N}=264)=56.783: \mathrm{p}<0.001)$ and individually between each stage $(\mathrm{p}<0.001)$. The curve describing the resistance dynamics was a mirror reflection of the curve representing egg volume increase. Figure 5 depicts the dynamics of the relationships expressed as percentages of the initial $\left(300 D^{\circ}\right)$ values.

\section{DISCUSSION}

Results obtained in this study demonstrated that eggs of the signal crayfish, similarly to eggs of other members of decapods in general, increase considerably in size during embryogenesis (WINNICKI and SŁOMIANKO, 1970) (HESSEN et al., 1987). This should be then regarded as a pattern that sets reproduction of that group of organisms apart from all higher animals in which reproduction via eggs laid and incubated outside of a maternal body was selected for as the most favourable pathway for the most important ontogenetic stages.

Similarly to those of other aquatic animals, the signal crayfish eggs vary in size (MASON, 1978). The variability is displayed both by the eggs produced by a single female and by those collected from different females. However, a certain relationship between egg size and the age (and thus the size) of a female has been detected (SKURDAL and QVENILD, 1986). 


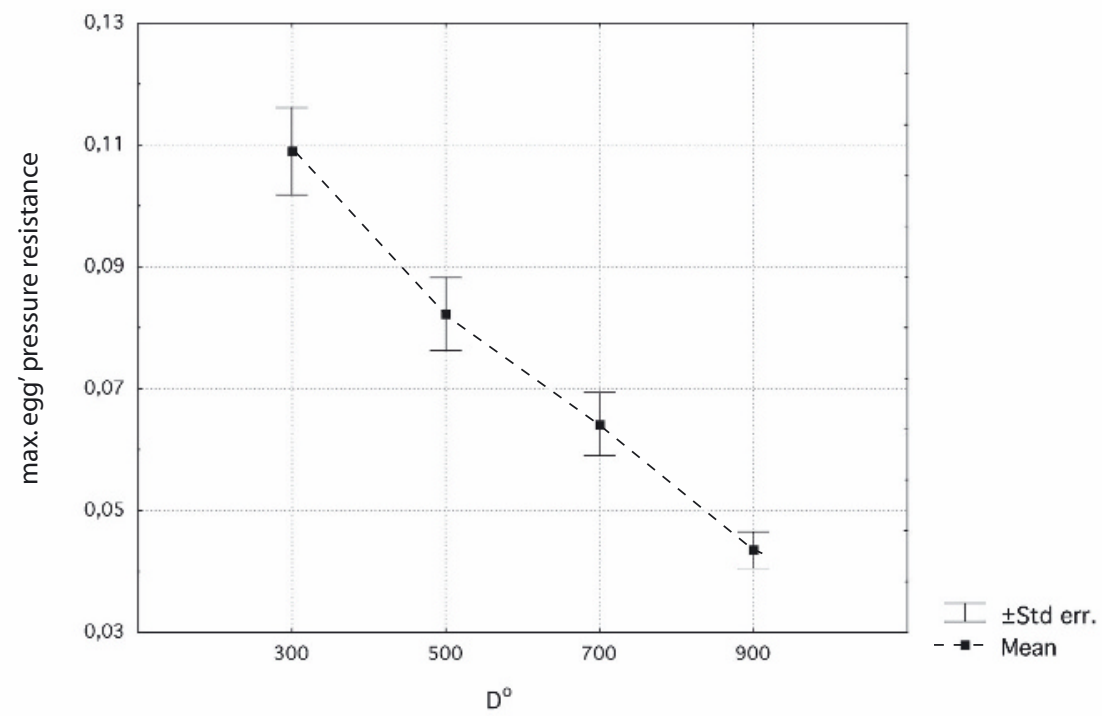

Figure 4

Changes in the signal crayfish ( $P$. leniusculus Dana) egg membrane resistance during embryogenesis. Kruskal-Wallis Test; H (df =3, $N=264)=56.783$; $p<0.001$.

Figure 4

Variations de la résistance membranaire des oeufs de l'écrevisse signal $(P$. leniusculus Dana) durant l'embryogenèse. Kruskal-Wallis Test; H (df $=3$, $\mathrm{N}=264)=56.783 ; \mathrm{p}<0.001$.

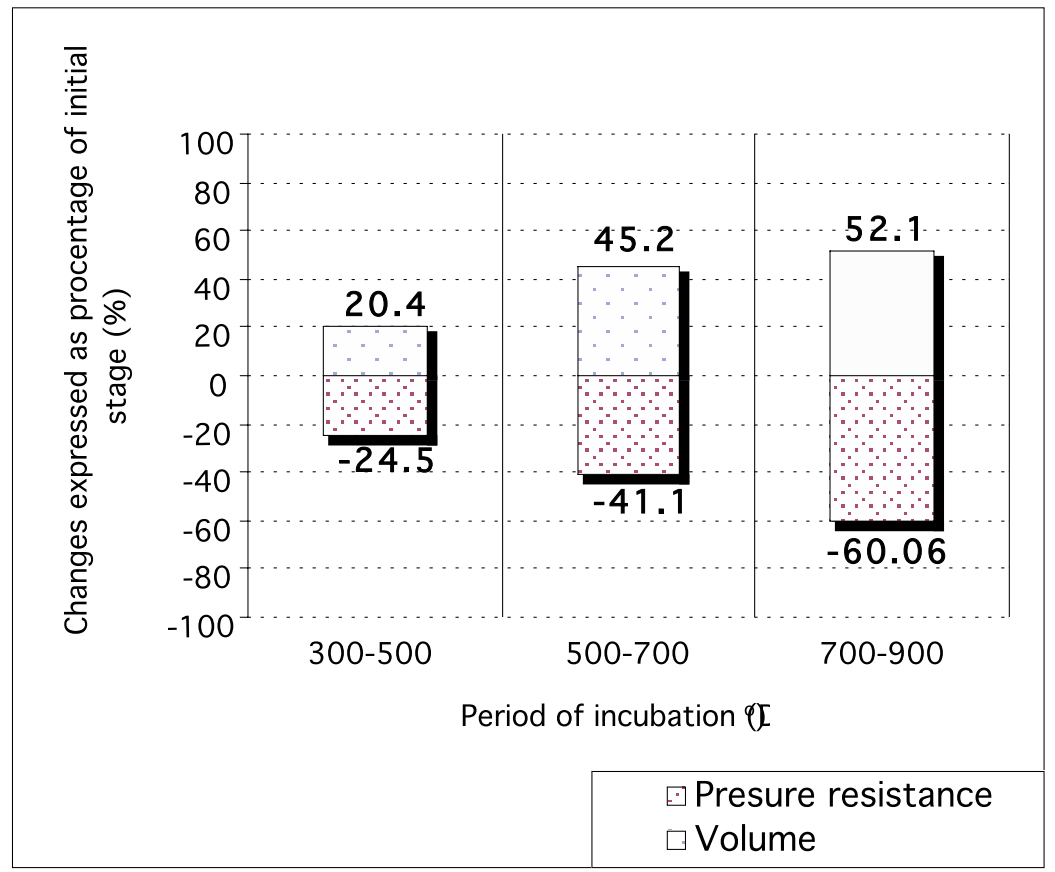

Figure 5

Per cent change in the signal crayfish (P. leniusculus Dana) egg volume and egg membrane resistance during embryogenesis.

\section{Figure 5}

Variations en pourcentage du volume et de la résistance membranaire des oeufs de l'écrevisse signal ( $P$. leniusculus Dana) durant l'embryogenèse. 
It should be mentioned here that the crayfish eggs lack a fluid-filled perivitelline space, which has not always been adequately acknowledged by some authors. To cite just one example, the classical perivitelline space in fish occurs between structures formed in the female ovary (vitelline membrane, membrana vitellaria) and the egg membrane (zona radiata, membrana radiata). The space between them is filled by water penetrating from the outside which then forms the perivitelline fluid. It constitutes a reservoir of more or less stable dimensions, surrounding the spherical yolk and an embryo emerging on its surface (WINNICKI, 1968; KORZELECKA et al., 1998; BONISLAWSKA et al., 1999. In contrast, the crayfish egg is surrounded by a vitelline membrane which is tightly covered by the egg sheath wall, for which reason no area deserving the name of vitelline space can be formed (RATHKE, 1829; HUXLEY, 1877).

Such structure of the external egg encasement, i.e., the absence of the perivitelline space, is not without advantages. Most importantly, the distance between the water surrounding the egg in the "brood chamber" and the body fluids of an embryonic structures (ectoplasm, germinal layers, etc.) developing on the surface of a centrolecithal egg is reduced to the minimum The development and growth of those structures requires a permanent supply of water which is directly absorbed from the outside, without a need to pass through a perivitelline space with its semi-permeable membranes. It is then natural that the constant and increasing demand for water and water absorption result in an increase in the volume of the entire system. Owing to the considerable flexibility of the egg cover, the egg grows in size. It should be mentioned that water absorption by the egg is a result of increasing osmotic pressure of body fluids of the newly forming embryo. That force induced by osmotic pressure has to be high enough to provide for an appropriate turgor of the egg and to stretch its membranes.

Thus, the egg volume increases with time, the increase being accompanied by a parallel increase in the egg surface. This is important because increasing surface means increasing respiration efficiency of the embryo for which the thin egg covers constitute the respiratory surface.

Finally, the considerable flexibility of egg membranes deserves mention. The flexibility as such is limited. The egg covers can be stretched up to a certain critical point only, after which they break down. That critical point is a measure of the general egg membrane resistance.

Characteristically, as found in this study, the egg membrane resistance is similar in the tested eggs. This is then evidence that biologically programmed flexibility and stretching ability is a factor ensuring normal embryogenesis. In this context, particularly noteworthy is the hatching mechanism. As in other decapods, the crayfish embryos hatch without the aid of any special hatching glands as their secretion is not necessary to perforate the egg membrane. For a regularly developing embryo, it is sufficient that water is absorbed (due to a difference in osmotic pressures between the two sides of the egg membranes) and the egg membranes are stretched up to the critical point; once the membranes break down, the embryo hatches.

The mechanism of crayfish hatching is poorly known, and hence difficult to discuss in the light of the present astacological knowledge. It seems, however, that the description of the physiology of the process may be of value for a better control of artificial incubation of the crayfish.

\section{REFERENCES}

BONISLAWSKA M., KORZELECKA A., WINNICKI A., 1999. Morpho-mechanical aspects of the embryonic development of sun bleak (Leucaspius delineatus Heck.) Folia Univ. Agric. Stetin. 192, ser. Piscaria (25), 13. 
CELADA J.D., Paz P., GAUDIOSO V.R., FERNÁNDEZ R., 1987. Embryonic development of the freshwater crayfish (Pacifastacus leniusculus Dana), a scanning electron microscopic study. Anat. Rec., 219, 304-310.

HAMR P., 1992. Embryonic and postembryonic development in the tasmanian freshwater crayfishes Actacopsis gouldi, Astacopsis franklinii and Parastacoides tasmanicus tasmanicus (Decapoda: Parastacidae). Austral. J. Mar. Fresh. Res., 43, 861-878.

HESSEN D., O., TAUGBØL T., FJELD E., SKURDAL J., 1987, Egg Development and Lifecycle Timing in the Noble Crayfish (Astacus astacus). Aquaculture, 64, 77-82.

HUXLEY T.H., 1877, The Crayfish. An introduction to the study of zoology. MIT Press.

KOSSAKOWSKI J., MNICH M., KOSSAKOWSKI G., 1978. The first introduction of the crayfish Pacifastacus leniusculus Dana into Polish waters. Freshwater Crayfish 4. IV International Symposium, Thonon les Bains, France, 195.

KRZYWOSZ T., 1994. The introduction of the crayfish Pacifastacus leniusculus Dana into Polish waters. Roczn. Nauk. PZW, 7, 81-93.

LEREBOULLET A., 1862. Recherches d'embryologie comparée sur le dévelopment du brochet, de la perche et de l'écrevisse. Mém. Acad. Sci. Inst. France, 17, 447805.

MASON J.C., 1978. Significance of egg size in the freshwater crayfish Pacifastacus leniusculus Dana. Freshwater Crayfish 4. IV International Symposium, Thonon les Bains, France, 83-92.

RATHKE H., 1829, Untersuchungen über die Bildung und Entwicklung des Flusskrebses. L. Voss, Leipzig.

SKURDAL J., QVENILD T., 1986, Growth, maturity and fecundity of Astacus astacus in Lake Steinsfjorden, S.E. Norway. Freshwater Crayfish, 6, 182-186.

ŚMIETANA P., STRUŻYŃSKI W., 1996: Uwagi do introdukcji raka sygnałowego (Pacifastacus leniusculus Dana) w wodach Polski. Chrońmy Przyrodę Ojczystą. PAN Instytut Ochrony Przyrody, 6, 118-121 (In Polish).

SUKO T., 1956. Studies on the development of the crayfish IV. The development of winter eggs. Sci. Rep. Saitama Univ., (B) 2 (2), 213-219.

WINNICKI A. 1968. Rola i wlasciwosci oslonek jajowych ryb lososiowatych. Wyd. WSR, Olsztyn. Habilitation dissertation. (In Polish)

WINNICKI A., SŁOMIANKO M., 1970. Taking-up of water by the eggs of the crab Rhithropanopeus harrisi (Gould) subsp. tridentatus (Maitland) during embryonic development. Zool. Pol., 20, 4, 415-422. 